\title{
Władysław Kowalenko - zapomniany poznański prekursor badań nad rolą morza dla studiów słowiańskich we wczesnym średniowieczu
}

Pośród wielu ważnych wydarzeń i okrągłych rocznic, w jakie obfituje bieżący rok 2016, pragnę zwrócić uwagę na jeszcze jedną, zupełnie zapomnianą. 15 czerwca 2016 r. upłynęło pięćdziesiąt lat od śmierci prof. Władysława Kowalenki. Wprawdzie tytuł niniejszego artykułu wskazuje po części na zakres problematyki badawczej tego uczonego, jednakże jest on o wiele szerszy i bardziej skomplikowany, podobnie jak jego postać jako człowieka i badacza oraz czasy, w których przyszło mu żyć. Kowalenko nie doczekał się dotąd szerszego opracowania ani biograficznego, ani odnoszącego się do jego dorobku naukowego. Pamięć o nim wyrażają jedynie niewielkie artykuły wspomnieniowe opublikowane krótko po śmierci, a także z okazji kolejnych okrągłych rocznic obchodzonych przez coraz węższe grono absolwentów założonej przez niego w 1945 r. Wyższej Szkoły Handlu Morskiego w Gdyni, oraz wspomnienia jego byłych uczniów będące formą wdzięczności za rozbudzenie w nich zainteresowań „pracą na morzu naszych ojców” ${ }^{1}$. Najobszerniejsza jak dotąd biografia Władysława Kowalenki, autorstwa Wincentego Swobody, ukazała się w pracy zbiorowej zawierającej biogramy wybitnych historyków

${ }^{1}$ W.A. Drapella, Uroczystość nadania auli Wydziału Ekonomiki Produkcji Uniwersytetu Gdańskiego imienia Profesora Wtadystawa Kowalenki. Sesja naukowa na temat 40-lecia Instytutu Morskiego przy Tajnym Uniwersytecie Ziem Zachodnich, „Kwartalnik Historii Nauki i Techniki” 1987, nr 32/2, s. 505-511; zob. także: Prof. dr hab. Władysław Kowalenko założyciel i dyrektor Instytutu Morskiego przy Tajnym Uniwersytecie Ziem Zachodnich w latach 1942-1944 organizator i pierwszy rektor Wyższej Szkoły Handlu Morskiego w latach 2945-1948, „Zeszyty Naukowe Wydziałów Ekonomiki Produkcji i Ekonomiki Transportu Uniwersytetu Gdańskiego" 1983, zeszyt specjalny, s. 5-175; W. Korcz, Wtadystaw Kowalenko - historyk Stowiańszczyzny na Bałtyku, „Przegląd Zachodniopomorski" 1983, t. 27, z. 3-4, s. 15-40. 
wielkopolskich, wydanej pod redakcją Jerzego Strzelczyka². Nie można pominąć też życiorysu Kowalenki autorstwa Elżbiety Lijewskiej, znajdującego się w sporządzonym przez nią wstępie do inwentarza archiwalnego jego spuścizny ${ }^{3}$. Jednak we wszystkich tych opracowaniach natrafiamy na wiele błędów, nieścisłości oraz niedomówień i przemilczeń.

Nazwisko Kowalenki umieszczone też zostało na tablicy pamiątkowej znajdującej się na terenie Uniwersytetu Gdańskiego, a odnaleziony w latach osiemdziesiątych $\mathrm{XX} \mathrm{w}$. $\mathrm{w}$ jednym $\mathrm{z}$ tamtejszych pomieszczeń za szafą portret $\mathrm{z}$ jego wizerunkiem uzupełnia galerię rektorów tej uczelni, która swymi tradycjami nawiązuje do dawnej, założonej z inicjatywy Kowalenki Wyższej Szkoły Handlu Morskiego. Prof. Kowalenko wymieniony jest także wśród przedstawicieli tzw. Myśli Zachodniej na poświęconej ich pamięci, odlanej z brązu tablicy, umieszczonej w krużgankach kościoła OO. Dominikanów w Poznaniu. Wspomniany jest on poza tym w Wielkopolskim stowniku biograficznym oraz $\mathrm{w}$ innych syntetycznych opracowaniach poświęconych historii nauki, które zasadniczo powielają wiedzę o nim zaczerpniętą z tego kompendium. Zawarte $w$ powyższych opracowaniach informacje, pomimo przypomnienia wielu faktów z życia profesora, mają suchy, encyklopedyczny charakter i w żaden sposób nie są $\mathrm{w}$ stanie przybliżyć losów tak barwnej i uwikłanej, w czasy w których przyszło mu żyć, postaci, jaką był Władysław Kowalenko. Chciałbym zatem bardziej szczegółowo go przedstawić, zwracając uwagę zarówno na rozwój jego zainteresowań badawczych, jak i na okoliczności zewnętrzne, które je determinowały, oraz na miejsca, w których $\mathrm{w}$ trakcie przeprowadzonej kwerendy znajdowałem materiały związane z Kowalenką. Pragnę jednak podkreślić, że największym i zarazem najważniejszym źródłem do poznania postaci Kowalenki i jego bogatej powojennej działalności organizacyjnej oraz naukowej jest jego spuścizna znajdująca się w Poznańskim Oddziale Archiwum PAN w Warszawie, zakupiona w 1966 r. od jego córki Haliny. Dzięki życzliwości kierownika Archiwum dr. Jarosława Matysiaka i jego współpracowników miałem okazję dokładnie przestudiować pozyskane dokumenty. Niestety, w spuściźnie tej zachowały się wyłącznie materiały z okresu powojennego. Wszystkie wcześniejsze dokumenty uległy zniszczeniu w czasie II wojny światowej, co stanowi spore utrudnienie w przypadku badania zarówno biografii, jak też pochodzących z tego okresu wyników badań naukowych profesora. $W$ trakcie prowadzonej kwerendy spostrzegłem znajdujące się we wszystkich niemal teczkach spuścizny puste metryczki, świadczące o tym, że jestem jedną z nielicznych osób badających

2 W. Swoboda, Wtadystaw Kowalenko 1884-1966, [w:] Wybitni historycy wielkopolscy, pod red. J. Strzelczyka, Poznań 2010, s. 339-348.

${ }^{3}$ Lijewska E., Materiały Władysława Kowalenki, Archiwum PAN Oddział w Poznaniu, sygn. P III - 29. 
ten zasób. Zdobytą wiedzę uzupełniałem, poszukując potrzebnych mi materiałów w: Archiwum UAM, Archiwum Biblioteki Uniwersyteckiej UAM, Dziale Zbiorów Specjalnych tejże, Archiwum Państwowym w Poznaniu, Instytucie Pamięci Narodowej w Poznaniu, Archiwum Muzeum Archeologicznego w Poznaniu, a także licznych bibliotekach. W miarę zagłębiania się w spuściźnie profesora zaczynałem coraz bardziej uświadamiać sobie, że Kowalenko to fenomen ówczesnych czasów. W trakcie 82-letniego życia dane mu było przeżyć kilka epok, z których każda wywarła piętno na jego dalszych losach zarówno w odniesieniu do życia prywatnego, jak i kierunku prowadzonych badań naukowych. Jego życie prywatne z powodzeniem mogłoby służyć za scenariusz do filmu. Urodził się, jak sam podaje, w Mińsku 9 września 1884 r. w rodzinie katolickiej. Jego rodzicami byli: Franciszek, urzędnik bankowy, i Helena z domu Brzostowska ${ }^{4}$. Miał młodszego brata Ambrożego. Po kilku latach wraz z rodziną wyjechał do Wilna, gdzie został uczniem jednego z tamtejszych gimnazjów, z którego został usunięty z nieznanych powodów (rzekomo za opór przeciw rosyjskim władzom szkolnym) i - jak podaje Swoboda - otrzymał „wilczy bilet”. Co ciekawe, edukację kontynuował w założonej przez cara po powstaniu styczniowym wileńskiej szkole junkrów piechoty, którą ukończył w 1904 r., otrzymując stopień oficerski. W 1905 r. wziął udział $\mathrm{w}$ wojnie rosyjsko-japońskiej, walcząc na froncie w Mandżurii. W 1908 r. zdał eksternistycznie maturę w Rosławiu w guberni smoleńskiej. W 1913 r. rozpoczął studia na wydziale filozoficzno-historycznym uniwersytetu w Petersburgu, gdzie wszedł w skład koła naukowego, któremu patronował znakomity lingwista Jan Baudouin de Courtenay (1845-1929) ${ }^{5}$. W sierpniu 1914 r. zmobilizowano go i skierowano na front, przez co musiał przerwać studia. $\mathrm{W}$ trakcie walk z armią pruską pod Warszawą został ranny, a po rozpadzie armii carskiej wziął udział w I Ogólnym Zjeździe Wojskowych Polaków w Piotrogrodzie, który odbył się w czerwcu 1917 r. Wchodził w skład jego Komitetu Głównego ${ }^{6}$, niestety, nie wiemy, jaką funkcję tam pełnił. W 1918 r. w Witebsku wziął ślub z Józefą z Maculewiczów primo voto Szrajber i zamieszkał w Święcianach koło Wilna, gdzie reaktywował w 1918 r. zamknięte przez władze carskie po powstaniu styczniowym polskie gimnazjum. Niebawem opuścił Święciany, uciekając w 1920 r. przed bolszewikami.

${ }^{4}$ Według błędnej informacji zawartej w aktach Urzędu Bezpieczeństwa w Poznaniu, Kowalenko urodził się w roku 1887 - zob. IPN sygn. Po 003/446/2. O błędnych datach narodzin Kowalenki (21 sierpnia 1884 r. oraz 3 września 1887 r.) przypomina także Wincenty Swoboda w napisanym przez siebie biogramie zamieszczonym w Polskim Stowniku Biograficznym (PSB), t. 14, Wrocław 1968-1969, s. 521-523.

${ }^{5}$ Informacje dotyczące przyczyn usunięcia Kowalenki z gimnazjum w Wilnie oraz jego udziału w walkach w Mandżurii w 1905 r. zaczerpnąłem z artykułu W. Swobody, dz. cyt., s. 339-348.

${ }^{6}$ M. Wrzosek, Polskie Korpusy Wojskowe w Rosji w latach 1917-1918, Warszawa 1969, s. 71. 
Tutaj pojawia się kolejne pytanie, dlaczego jako były carski oficer nie wziął czynnego udziału w wojnie z bolszewikami? Najpierw wyjechał do Torunia, a stamtąd w rok później udał się do Poznania, gdzie w 1921 r. rozpoczął studia historyczne i archeologiczne zakończone w 1925 r. obroną pracy doktorskiej napisanej pod kierunkiem prof. Kazimierza Tymienieckiego pt. Udział Wilna w sejmach Rzeczypospolitej ${ }^{7}$. Nawiązał też trwające do końca życia przyjacielskie kontakty z prof. Józefem Kostrzewskim, pod którego kierunkiem prowadził dalszą pracę naukową uwieńczoną habilitacją z zakresu archeologii pt. Grody i osadnictwo grodowe Wielkopolski wczesnohistorycznej w VII-XII w. ${ }^{8}$ Praca ta była pierwszą tego typu syntezą nowatorską pod względem metodologicznym, łączącą w sobie niespotykane wówczas w nauce interdyscyplinarne - zarówno z punktu widzenia historyka, jak i archeologa - spojrzenie na zagadnienie powstawania oraz lokalizacji grodów i osad na terenie Wielkopolski. Równolegle z pracą naukową uczył historii do $1926 \mathrm{r}$. w gimnazjum im. Ignacego Paderewskiego, a następnie (do 1939 r.) w gimnazjum im. Bergera i Liceum Handlowym w Poznaniu, prowadząc jednocześnie ożywioną działalność społeczną w Zarządzie Okręgu Towarzystwa Nauczycieli Szkół Średnich i Wyższych na województwa poznańskie i bydgoskie oraz w Lidze Morskiej i Kolonialnej, będąc zarazem członkiem Zarządu Głównego i publikując wiele artykułów na tematy morskie w czasopismach „Morze” i „Sprawy Morskie i Kolonialne". Trudno powiedzieć, na jakim etapie życia narodziła się w nim morska pasja, której pozostał wierny aż do końca. Może właśnie wtedy poznał głównego orędownika morskiego otwarcia Polski na świat, ministra przemysłu i handlu II Rzeczypospolitej a zarazem budowniczego portu w Gdyni inż. Eugeniusza Kwiatkowskiego, z którym po wojnie założył w Sopocie Wyższą szkołę Handlu Morskiego? W lipcu i sierpniu 1938 r. zorganizował dla uczniów gimnazjum im. Bergera trwający sześćdziesiąt dni i liczący 1500 km rejs żeglarski od wschodniej aż do zachodniej granicy Polski ze Stołpców nad Niemnem do Międzychodu nad Wartą. Jednak za swoją popularność w gronie uczniów i późniejszych absolwentów gimnazjum przyszło mu po wojnie, w czasach PRL, tj. począwszy od wczesnych lat pięćdziesiątych XX w., zapłacić wieloletnią inwigilacją i prześladowaniem ze strony Urzędu Bezpieczeństwa, który ostatecznie zamknął jego sprawę, przekazując materiały do archiwum dopiero w 1972 r., a więc sześć lat po śmierci profesora. Jest to dotychczas zupełnie nieznana karta z życia Kowalenki. Nie wspomina o niej żaden z jego dotychczasowych biogramów, nie słyszał także o tym jego dawny wieloletni współpracownik prof. Andrzej Wędzki ${ }^{9}$. Materiały te,

\footnotetext{
${ }^{7}$ Praca ta została opublikowana w „Ateneum Wileńskim” 1925-1926, t. 3; 1927, t. 4.

${ }^{8}$ W. Kowalenko, Grody i osadnictwo grodowe Wielkopolski wczesnohistorycznej (od VII do XII w.), Poznań 1938.

${ }^{9}$ Prof. Andrzej Wędzki, ur. 1929. Od 1953 r. był zatrudniony w redakcji Stownika starożytności słowiańskich i pracował wraz z Kowalenką przez trzynaście lat, aż do jego śmierci w $1966 \mathrm{r}$. Od 1983 r. kierował redakcją SSS do czasu ukazania się jego ostatniego, ósmego tomu w 1996 r.
} 
liczące ponad dwieście jednostek, znajdują się obecnie $\mathrm{w}$ poznańskim Oddziale Instytutu Pamięci Narodowej ${ }^{10}$. W czasie II wojny światowej wielu byłych uczniów i wychowanków Kowalenki z poznańskiego gimnazjum Bergera, w tym także członków założonego przez niego szkolnego Koła Ligi Morskiej i Kolonialnej, wstąpiło w konspiracyjne struktury Armii Krajowej i działało w siatce wywiadowczej pod kryptonimem „Lombard”. Dostarczała ona do Londynu informacje na temat: niemieckiego przemysłu zbrojeniowego, dyslokacji wojska, rozmieszczenia ośrodków badawczych itp. To właśnie dzięki informacjom uzyskanym od "Lombardu” możliwe stało się zbombardowanie niemieckiej fabryki rakiet V1 i V2 w Peenemünde. Po zakończeniu wojny „Lombard” został przejęty przez wywiady brytyjski i amerykański. Wkrótce też jego agenci zaczęli być rozpracowywani przez UB. Niektórzy z nich, nie wiedząc, że są śledzeni, próbowali nawiązać kontakt ze swym dawnym wychowawcą i opiekunem. Brakuje przesłanek, by twierdzić, jakoby próbowali oni wciągnąć Kowalenkę w działalność wywiadowczą. Jednak sama próba nawiązania z nim kontaktu skłoniła UB do wieloletniej inwigilacji profesora, polegającej na: założeniu kartoteki jako podejrzanemu o szpiegostwo, kontrolowaniu jego korespondencji, wzywaniu na przesłuchania, gromadzeniu przeciwko niemu donosów, śledzeniu w trakcie podróżowania po kraju ${ }^{11}$. Trudno powiedzieć, czy i w jakim stopniu to długotrwałe poczucie zagrożenia, w jakim się znalazł, odbiło się na psychice i stanie zdrowia profesora. Wiadomo jednak, że UB żadnego ze swych podejrzeń nie zdołał mu udowodnić. W 1939 r. Kowalenko otrzymał od prof. Kostrzewskiego rekomendację na wakujący etat $\mathrm{w}$ Katedrze Prehistorii na Uniwersytecie Stefana Batorego w Wilnie. Propozycja została w Wilnie zarówno przez rektora, jak i senat uniwersytetu pozytywnie przyjęta, jednak po proteście Tadeusza Sulimirskiego, profesora prehistorii Uniwersytetu Jagiellońskiego, Kostrzewski wycofał rekomendację na rzecz innego swego ucznia Konrada Jażdżewskiego ${ }^{12}$. We wrześniu 1939 r. Kowalenko wyjechał do Warszawy. Po wkroczeniu wojsk niemieckich jako zakładnik został uwięziony na Pawiaku, gdzie przebywał od listopada do grudnia 1939 r. Po wypuszczeniu z Pawiaka pozostał w Warszawie, a w 1940 r. dołączyły do niego wysiedlone z Poznania żona z córkami ${ }^{13}$. Tam też w 1940 r., wraz z prof. Ludwikiem Jaxa-Bykowskim,

10 Sygn. IPN Po 003/446/2.

${ }^{11}$ M.in. w trakcie pobytu Kowalenki na Wolinie w celu zapoznania się z wynikami prowadzonych tam badań archeologicznych pracownik szczecińskiego Urzędu Bezpieczeństwa zapytuje poznański Urząd Bezpieczeństwa, w jakim celu profesor porusza się po tamtym terenie. Zob. IPN sygn. Po.003/446/2.

12 K. Jażdżewski, Pamiętniki. Wspomnienia polskiego archeologa z XX wieku, Łódź 1995, s. 132.

13 Żona Kowalenki Józefa wraz z córką Haliną były umieszczone w spisach osób przeznaczonych do wysiedlenia z Poznania w latach 1939-1940. Zob. Archiwum Państwowe w Poznaniu, nazwa zespołu: Umwanderzentralstelle Posen, k. 148. 
prof. Romanem Pollakiem i ks. dr. Maksymilianem Rode powołał do życia Uniwersytet Ziem Zachodnich (UZZ), którego działalność zainaugurowała cicha msza św. odprawiona 24 września 1940 r. przez ostatniego z wymienionych. Początkowo Kowalenko wykładał na nim historię Słowian zachodnich i średniowiecza oraz prehistorię. Wszedł także w skład utworzonego przez Halinę Regulską komitetu samopomocy opiekującego się naukowcami UZZ ${ }^{14}$. Był też kronikarzem Uniwersytetu, lecz wszystkie posiadane materiały związane z jego działalnością uległy zniszczeniu w czasie powstania warszawskiego. W trzecim roku akademickim (1942/43) na UZZ powołano nowe, mające prawa osobnego wydziału, wyższe morskie studium gospodarcze pod nazwą Instytut Morski. Jego dyrektorem został doc. Kowalenko (pseud. Sternicki). Było to pierwsze w Polsce studium ekonomiczno-morskie przygotowujące młodzież na poziomie akademickim do pracy administracyjno-gospodarczej związanej z obsługą portów i handlem morskim. Kowalenko wykładał tu dzieje żeglugi i polityki morskiej oraz historię polskiej polityki morskiej. Powstanie, organizację i przebieg pracy UZZ uwiecznił Kowalenko $\mathrm{w}$ napisanej po wojnie, na podstawie zebranych wspomnień wykładowców i studentów, pracy, która do dzisiaj jest jedynym tak obszernym opracowaniem przedstawiającym działalność Uniwersytetu Poznańskiego w latach okupacji ${ }^{15}$. Praca ta została po raz pierwszy wydana $w$ skróconej wersji w 1946 r., a przed jej wznowieniem na początku lat 60. XX w. Kowalenko zebrał liczne relacje zarówno od wykładowców, jak i od studentów UZZ. Informacje w nich zawarte zostały częściowo wykorzystane w jej drugim wydaniu z 1961 r., a wiele materiałów nieopublikowanych znajduje się wraz z maszynopisem tej pracy w Dziale Zbiorów Specjalnych Biblioteki UAM i częściowo także w jego spuściźnie w Oddziale Archiwum PAN w Poznaniu. Wśród nich na uwagę zasługuje recenzja napisana przez byłego rektora UZZ prof. Romana Pollaka. Pomimo widniejącej na niej odręcznej notatki Kowalenki, aby ją załączyć na końcu przygotowywanej do wydania książki, nie została ona tam umieszczona. Pollak zwraca w niej uwagę m.in. na okoliczności śmierci prof. Tadeusza Chrząszcza, przez krótki czas dziekana Wydziału Rolnego UZZ. Według oficjalnej wersji, miał on popełnić samobójstwo, zażywając truciznę w momencie aresztowania go przez gestapo. Jednak zdaniem prof. Pollaka, denuncjował on do gestapo wiele osób, m.in. jego oraz prof. Sta-

${ }^{14}$ Szerzej udział Kowalenki w komitetach samopomocy niosących pomoc wykładowcom UZZ opisuje Regulska, która wraz z prof. Pollakiem i doc. Kowalenką oraz innymi naukowcami usuniętymi przez hitlerowców z Poznania i tamtejszego uniwersytetu współtworzyła działający w Warszawie w latach okupacji Tajny Uniwersytet Ziem Zachodnich (UZZ). Jej wspomnienia przynoszą mało znane szczegóły dotyczące powstania i codziennej pracy tej zasłużonej placówki. Zob. H. Regulska, Tamte lata, tamte czasy. Wspomnienia z II wojny światowej, Wrocław 1988.

${ }^{15}$ W. Kowalenko, Tajny Uniwersytet Ziem Zachodnich. Uniwersytet Poznański 1940-1945, Poznań 1961. 
nisława Glixellego jako osoby rzekomo żydowskiego pochodzenia, za co otrzymał od Armii Krajowej wyrok śmierci. Prof. Pollak pisał: „W istocie zaś nazwisko to należy ze spisu ofiar hitleryzmu wykreślić i z tablicy w Sopocie bez śladu wyskrobać". Jednak czas okazał się bardziej łaskawy dla prof. Chrząszcza. Dzisiaj jego imię nosi jeden z budynków Uniwersytetu Przyrodniczego w Poznaniu przy ul. Wojska Polskiego, a dodatkowo zdobi go wystawiony w 2012 r., umieszczony na głazie pomnik, poświęcony temuż profesorowi. Kowalenko brał też udział w powstaniu warszawskim i wyszedł z niego cały i zdrowy, jednak nic nie wiadomo, aby walczył zbrojnie w oddziałach AK. Od listopada 1944 do lutego 1945 r. przebywał w Starachowicach, a w marcu 1945 r. powrócił do Poznania, prowadząc na tutejszym uniwersytecie jako prof. tytularny wykłady z historii żeglugi i polityki morskiej, rozszerzając w 1946 r. swoją habilitację na całe dzieje Słowiańszczyzny wczesnośredniowiecznej. Początkowo starał się reaktywować Instytut Morski w ramach Uniwersytetu Poznańskiego, jednak propozycja ta nie spotkała się z większym zainteresowaniem. Mając poparcie Ministerstwa Żeglugi i Handlu Zagranicznego, uruchomił w 1945 r. w Sopocie Wyższą Szkołę Handlu Morskiego, zostając jednocześnie jej dyrektorem. Miała ona charakter placówki przygotowującej młodzież do zawodu, ale nie posiadała charakteru naukowo-badawczego. Wykładał w niej m.in. Eugeniusz Kwiatkowski, będący wówczas pełnomocnikiem ds. odbudowy Wybrzeża. Obydwaj utracili stanowiska w 1948 r. z powodu swych "reakcyjnych" poglądów. Jednak Kowalenko - najprawdopodobniej dzięki osobistym powiązaniom z wysoko postawionymi urzędnikami w Ministerstwie Oświaty (z dokumentów wynika, że posiadał dobre kontakty z ówczesnym ministrem oświaty Czesławem Wycechem, dyrektorem departamentu szkolnictwa wyższego Włodzimierzem Michajłowem i wiceminister Eugenią Krassowską), pochodzącymi zapewne z czasów jego działalności na UZZ - otrzymał status prof. tytularnego Uniwersytetu Poznańskiego (UP) i utworzoną ad personam katedrę, którą nazwał Katedrą Historii Żeglugi i Polityki Morskiej. Jednak już w czerwcu 1950 r. katedra została zlikwidowana, a Kowalenko wyrzucony z uczelni. Nie miało to jednak związku z powszechnym w tym czasie "usuwaniem przeżytków reakcyjnej profesury", co dotknęło wielu wybitnych naukowców ${ }^{16}$. Ze znajdujących się w posiadaniu Instytutu Pamięci Narodowej akt Urzędu Bezpieczeństwa wynika, że bezpośrednim i jedynym sprawcą wyrzucenia Kowalenki był Bolesław Kuryłowicz, ówczesny prorektor UP. Uczynił to tak skutecznie, że kiedy po okresie tzw. odwilży, w 1958 r. Kowalenko prosił ów-

${ }^{16}$ Szerzej na ten temat zob. T. Schramm, Kilka mniej znanych kart z dziejów Uniwersytetu Poznańskiego, Poznań 1994. Zob. także Archiwum Państwowe w Poznaniu, POP Uniwersytet Poznański. Protokoły konferencji, planów, egzekutyw 1949-1951. KU PZPR UAM Poznań sygn. 1 i 2. 
czesnego rektora UAM prof. Alfonsa Klafkowskiego o reaktywowanie studiów historii żeglugi i polityki morskiej, to pomimo pozytywnej uchwały w tej sprawie Rady Wydziału Filozoficzno-Historycznego i zatwierdzenia jej przez Senat, nie otrzymał jego zgody, z powodu rzekomego „braku kwalifikacji do wykładania”. Nie otrzymał też zgody rektora na prowadzenie bezpłatnych wykładów z tego zakresu. Po wyrzuceniu z UP z pomocą Kowalence przyszedł prof. Zygmunt Wojciechowski, angażując go w kierowanym przez siebie Instytucie Zachodnim (IZ) na stanowisku kierownika sekcji dziejów Pomorza i Słowiańszczyzny Zachodniej. W tym czasie Kowalenko napisał kilka cennych prac o grodach portowych nad Bałtykiem, żegludze Słowian nadadriatyckich i innych zagadnieniach związanych z żeglugą Słowian, opublikowanych w "Przeglądzie Zachodnim”. W roku 1954 komitet redakcyjny Stownika starożytności słowiańskich powierzył Kowalence kierownictwo sekretariatu naukowego tego wydawnictwa. Na tym stanowisku, przeszedłszy na etatdocenta, a później profesora nowo powstałegoZakładuSłowianoznawstwa PAN, pracował aż do przejścia na emeryturę w 1960 r. Nadal jednak jako jeden z redaktorów był tam zatrudniony na zlecenie aż do śmierci $\mathrm{w} 1966 \mathrm{r}$. W 1955 r. na wniosek Zakładu Słowianoznawstwa PAN otrzymał tytuł prof. nadzwyczajnego. Były to lata intensywnej pracy, w trakcie której napisał 160 haseł do Stownika oraz jedenaście artykułów sprawozdawczych z przebiegu prac nad organizacją wydawnictwa. Dwukrotnie w ramach przygotowywanej pracy nad miastami romańskimi na tle stosunków ze Słowianami adriatyckimi od VII do VIII w. wyjeżdżał do Jugosławii (w latach 1957 i 1959) ${ }^{17}$. Celem tych wyjazdów, poza zapoznaniem się z niedostępną w Polsce literaturą opisującą najnowsze badania nad południową Słowiańszczyzną, niezbędną przy redagowaniu haseł dla SSS, było także zbieranie materiałów do większego zamierzenia naukowego, którego częścią była wyżej wspomniana praca, a które miało przynieść wyczerpującą monografię zagadnień morskich całej wczesnośredniowiecznej Słowiańszczyzny. Niestety, do realizacji tego dzieła nie doszło. Po przejściu w 1960 r. na emeryturę Kowalenko nie zaprzestał aktywności naukowej. W jednym z listów ówczesny dyrektor Zakładu Słowianoznawstwa PAN prof. Tadeusz Lehr-Spławiński napisał do profesora, że „nie wyobraża sobie bez niego dalszej pracy nad SSS i zatrudnia go na pracach zleconych". 2 lipca 1962 r. w kolejnym liście tak napisał do Kowalenki: „SSS wyrobił sobie już dobrą markę i wymienia się go między najważniejszymi publikacjami PAN. Wszystko to się Panu zawdzięcza. Pańskiemu umiłowaniu przedmiotu i wytrwałości. Współpracownikom Pańskim należy się też dużo uznania za gorliwość i sumienność w pracy - proszę im to ode mnie oświadczyć". Jednak mocne dotąd zdrowie zaczynało Kowalence odmawiać posłuszeństwa. W 1960 r. przeszedł zawał serca, trzy lata później w czasie

17 Praca ta została opublikowana w „Pamiętniku Słowiańskim” 1959, t. 9, s. 51-113. 
mgły potrącił go samochód, a z początkiem $1966 \mathrm{r}$. kilka kolejnych udarów mózgu doprowadziło do śmierci. Zmarł 15 czerwca 1966 r. Został pochowany na cmentarzu na Junikowie w Poznaniu. W dwa tygodnie później zmarła także jego żona.

Z przedstawionego powyżej, mocno skróconego życiorysu, będącego zarazem tłem, na którym dojrzewały i rozwijały się naukowe zainteresowania prof. Kowalenki, widać wyraźnie, że bliższe podjęcie przez niego problematyki Słowian zachodnich datuje się na okres II wojny światowej i ma ono bezpośredni związek z jego działalnością jako wykładowcy na UZZ. Zarówno bliskie kontakty z prof. Kostrzewskim, jak i zainteresowania badawcze związane $\mathrm{z}$ osadnictwem grodowym oraz tematyką morską $\mathrm{w}$ zetknięciu $\mathrm{z}$ barbarzyństwem lat okupacji i udziałem $\mathrm{w}$ tajnym nauczaniu zaowocowały bezpośrednim ukierunkowaniem refleksji naukowej Kowalenki w stronę Słowiańszczyzny zachodniej. Niewątpliwie jednak wydana w 1938 r. jego rozprawa habilitacyjna Grody i osadnictwo grodowe Wielkopolski wczesnohistorycznej (od VII do XII w.) dobrze przygotowała Kowalenkę w sensie merytorycznym do podjęcia badań nad zagadnieniami związanymi z grodami portowymi nad Bałtykiem, którym poświęcił wiele swoich późniejszych prac. Zawierała ona rezultat wieloletnich badań polegających nie tylko na zbieraniu istniejącej już dokumentacji, ale także na rozsyłaniu kwestionariuszy badawczych do właścicieli majątków na terenach których mogły znajdować się grodziska, jak również osobistemu prowadzaniu powierzchniowych poszukiwań $w$ terenie, które rozpoczął już w 1922 r. Warto też wspomnieć, że jako jeden z pierwszych w Polsce archeologów wykorzystywał do swoich badań zdjęcia lotnicze. Wszystkie te prace zaowocowały zlokalizowaniem 544 grodzisk leżących na terenie środkowej i zachodniej Wielkopolski, pochodzących z różnych okresów, począwszy od kultury łużyckiej, skończywszy na średniowieczu. Pomimo że Kowalenko w kwestii dotyczącej osadnictwa słowiańskiego w pełni podzielał zdanie swego mistrza prof. Kostrzewskiego, mającego całkowicie odmienne poglądy od uczonych niemieckich, to jednak jego praca o osadnictwie grodowym Wielkopolski wczesnohistorycznej została w czasie II wojny światowej przetłumaczona na język niemiecki i była wykorzystywana przez tamtejszych archeologów w utworzonej przez okupanta w Poznaniu instytucji badawczej noszącej nazwę Landesamt für Vorgeschichte ${ }^{18}$. Do dzisiaj w teczkach zawierających wyniki badań poszczególnych grodzisk znajdują się fiszki z przetłumaczonymi na niemiecki, odnoszącymi się do nich fragmentami książki Kowalenki. Koleje losu, które sprawiły, że Kowalenko ostatnie lata swego długiego i do końca aktywnego naukowo życia związał z Instytutem Zachodnim i redakcją SSS, dały mu możliwość w pełni poświęcić się badaniom nad Słowiańszczyzną. Rozpoczynając pracę w IZ, w przedstawionym

${ }^{18}$ Archiwum Muzeum Archeologicznego w Poznaniu, sygn. MAP-A-dz-65/2. 
jego sekretarzowi naukowemu prof. Zdzisławowi Kaczmarczykowi 19 lutego 1951 r. planie badań na najbliższe lata, zapowiadał „realizowanie uznanego za niezbędny szerokiego planu dziejów Słowiańszczyzny Zachodniej i historii Pomorza. Słowiańszczyznę Zachodnią należy opracowywać etapami począwszy od dziejów Zachodnich Słowian Bałtyckich. Tworzą bowiem oni pod względem terytorialnym i językowym najbardziej do Polski [sic!] zbliżoną grupę etniczną. Nauka polska nie uwzględniła w dostatecznym stopniu współzależności politycznej ich dziejów z dziejami polskimi i wzajemnych oddziaływań kulturalnych. Szczególnie zaś zaniedbany jest odcinek stosunków gospodarczych: produkcja rolna, rybołówstwo, solewarstwo [sic!], rzemiosła, handel i żegluga"19. Jak już wspomniałem, główną dziedziną zainteresowań Kowalenki były dzieje Słowiańszczyzny ze szczególnym uwzględnieniem roli Słowian na morzu. Praca w IZ otworzyła przed nim możliwość publikowania artykułów na łamach „Przeglądu Zachodniego”, jednego z nielicznych czasopism naukowych ukazujących się regularnie w owym czasie w Polsce . Skwapliwie skorzystał on z tej możliwości. Najważniejsze jego rozprawy drukowane były w "Przeglądzie Zachodnim” w latach 1950-1960 i realizowane były zgodnie z tezą, że aby oświetlić rolę Słowian na Bałtyku, należy przebadać podstawę ich ruchliwości i siły na morzu, wywodzących się w prostej zależności od rozbudowanych na wybrzeżu grodów portowych. Był to zasadniczy punkt wyjścia dla uzyskania właściwego obrazu ilustrującego miejsce Słowian na Bałtyku. Całe bowiem południowe wybrzeże Bałtyku w V i VI w. pod względem etnicznym, jak stwierdzał Kowalenko, było jednolicie słowiańskie i takim pozostało przez osiem wieków, aż do początków kolonizacji niemieckiej. Wraz z upadkiem grodów portowych i rozwijającej się kolonizacji niemieckiej w XIII w. kończy się rola Słowian na Bałtyku. Polemizował też z nauką niemiecką, która odkrytą w Charbrowie łódź słowiańską uznawała za wikińską. Działalność Słowian na Bałtyku uzupełnia i rozszerza o pewne szczegóły o charakterze lokalnym studium Najdawniejszy Kołobrzeg $(\text { VIII-XIII } w \text {. })^{20}$. Kolejne studium o osadnictwie i szlakach komunikacyjnych obejmowało wyspy Uznam i Wolin wraz z Zalewem Szczecińskim i nosiło tytuł Piana, Świna i Dziwna jako szlaki osadniczo-komunikacyjne Słowiańszczyzny Bałtyckiej VIII-XIII w. ${ }^{21}$ Kowalenko pisał w nim: „Ten wielecko-pomorski odcinek Wybrzeża oparty o wyspy Uznam i Wolin, przez kilka wieków (VII-XII) był podstawową bazą Słowiańszczyzny bałtyckiej pod względem gospodarczym i politycznym". Wszystkie grody znad Piany i Dziwny powstały i rozwijały się w najściślejszym związku z portami. Jest to generalna zasada ówczesnego osadnictwa w każdym poszczególnym wypadku. Gród i port były

\footnotetext{
19 Archiwum PAN Oddział w Poznaniu, sygn. P-III-29/82.

20 "Przegląd Zachodni" 1951, r. 7, nr 7-8, s. 538-576.

21 "Przegląd Zachodni" 1954, r. 10, nr 1-2, s. 1-90.
} 
niezmienną funkcją zasiedlenia ludności żyjącej z morza, były zjawiskiem socjalno-gospodarczym. W bliskim związku z badaniami słowiańskiej żeglugi pozostaje kolejna praca Kowalenki pt. Przewtoka na szlaku żeglugowym WartaGopto-Wisła22. Mowa w niej o pośrednich drogach do morza poprzez spławne rzeki i jeziora oraz o tym, że w IX-XII w. szlaki wodne miały przeważające znaczenie nad lądowymi. (Obecnie dawną przewłokę pomiędzy dorzeczem Odry i Wisły zastąpił łączący Wartę z Gopłem kanał o długości 32 km). Szlak wodny wykluczał ryzyko błądzenia i ułatwiał przejazd do wybrzeża morskiego. Kolejna jego praca opublikowana w "Przeglądzie Zachodnim” w 1954 r. nosiła tytuł Battyk i Pomorze w historii kartografii (VII-XVI w. $)^{23}$. Autor wyjaśnia w niej m.in., że bodźcem do rozwoju polskiej kartografii była życiowa potrzeba i konieczność odzyskania dostępu do morza oraz szybki rozwój nauki geografii w Akademii Krakowskiej. Obydwie te dążności łączyły się w walkach o Pomorze i wybrzeże morskie. Podejmując badania nad działalnością Słowian południowych na Adriatyku, Kowalenko stwierdzał, że: „Dzieje słowiańskiego wybrzeża Bałtyku wykazują pod pewnymi względami dużo wspólnych cech z wybrzeżem adriatyckim, ale Bałtyk ma o wiele wcześniejsze związki ze Słowianami niż Adriatyk". Podkreślał także, że Słowianie Zachodni ulegli germanizacji, natomiast na południu było odwrotnie, tam miejscowa ludność romańska uległa stopniowej slawizacji.

W sferze marzeń profesora pozostawała myśl o powołaniu do życia na wzór ukazujących się czasopism "Slavia Antiqua” czy "Slavia Occidentalis” czasopisma "Slavia Maritima”, poświęconego zagadnieniom historii żeglugi. Podkreślał, że „przy takim czasopiśmie w przyszłości można skupić wartościowy zespół współpracowników do badań nad dziejami mórz, przede wszystkim ze środowisk uniwersyteckich i towarzystw naukowych. Poza tym inicjatywie naszej przyświeca też inny cel, polegający na wykazaniu fałszywości poglądów panujących na Zachodzie, zwłaszcza szerzonych przez Niemców rewizjonistów, że Słowianie w średniowieczu nie znali morza i nic na nim nie znaczyli, co służyło im za argument natury politycznej. Wiemy, że było inaczej, że Słowianie bałtyccy wnieśli duży wkład w dorobek kultury morskiej na Bałtyku. Przypadł on Niemcom wraz z portami słowiańskimi od Lubeki po Gdańsk w okresie skolonizowania naszego wybrzeża. Polska jest strażnicą Zachodniej Słowiańszczyzny od wieków i dotąd jej rola nie uległa zmianie".

Z artykułów popularnonaukowych Kowalenki na uwagę zasługuje artykuł zamieszczony w 1954 r. w czasopiśmie „Wiedza i Życie” pt. Przeszłość dziejowa Słowian na Bałtyku²4. Kończąc go, podkreślał, że „kres potędze Słowian

\footnotetext{
22 „Przegląd Zachodni" 1952, r. 8, nr 5-6.

23 "Przegląd Zachodni" 1954, r. 10, nr 7-8, s. 353-389.

24 „Wiedza i Życie” 1954, r. 21, nr 6, s. 372-379.
} 
na Bałtyku położyli Duńczycy gdy w 1184 r. w ostatniej bitwie morskiej w pobliżu Gryfii rozbili flotę księcia Bogusława I. Datą tą kończymy nasz przegląd pracy i bojów Słowian bałtyckich na morzu. Gospodarowali oni na nim co najmniej przez 5 wieków. Wykazali duże zdolności twórcze w rzemiośle, handlu, budownictwie, sztuce i organizowaniu wielkich flot. Stworzyli liczne grody portowe. $\mathrm{W}$ nich pracowali i bronili swego bytu. $\mathrm{Z}$ ich upadkiem stracili swoją niezależność. Owoce ich pracy i doświadczenia morskie weszły w dzieje innych narodów i znane są pod obcymi tytułami. Przeszłość dziejowa Słowian na morzu poszła w zapomnienie. Dlatego restytucja z otchłani wieków dorobku na morzu Słowiańszczyzny Zachodniej jest koniecznym i pięknym zadaniem nauki polskiej".

Na koniec pragnę podkreślić wkład Kowalenki w powstanie SSS. Pracy nad nim poświęcił ostatnie dwanaście lat swego życia. Trafnie ujął to jeden ze stałych recenzentów powstających kolejnych tomów SSS prof. Stanisław Urbańczyk: „Redaktorów SSS było trzech: Lehr-Spławiński, Wojciechowski i Kowalenko. Właśnie ten ostatni był do roboty, on pilnował biegu spraw. Wprawdzie jego specjalność - historia żeglugi - była tu mało przydatna, ale jego pracowitość była bezcenna. Cała trójka po kolei dość rychło umarła, więc faktyczna władza przeszła w ręce Labudy. Współredaktorem został Stieber jako dyrektor Instytutu Słowianoznawstwa, który z czasem przejął Słownik do swego planu. Wielką rolę odegrali młodzi historycy, na stałe zamówieni do uładzenia i kontroli nadsyłanych opracowań" 25 . Jednym z wyrazów zaangażowania Kowalenki w powstawanie SSS było kilkanaście artykułów, w których rozważał problemy Słownika. W latach 1956-1961 w różnych czasopismach informował on o stanie przygotowań nad wydawnictwem Stownika, jego charakterem, trudnościach w kompletowaniu materiałów itp. Osobnym zagadnieniem, które zainteresowało redakcję SSS, a czemu dawał wyraz prof. Kowalenko, były głosy uczonych innych krajów krytykujących samą koncepcję lub wyrażających pełną aprobatę i zgłaszających swoją współpracę. Jeden z pierwszych artykułów zapowiadających powstanie Stownika napisany przez niego wspólnie z prof. Lehr-Spławińskim i opublikowany w 1956 r. w "Nauce Polskiej", nosił tytuł Czym ma być i jak powstaje SSS ${ }^{26}$. Następne artykuły autorstwa Kowalenki, przedstawiające kolejne etapy powstawania SSS, pojawiły się w tym samym roku w „Przeglądzie Zachodnim”. Były to: Z pracowni SSS w Poznaniu, O konieczności synchronizowania wspótpracy nad SSS, Osiem lat pracy nad SSS na tle prób wcześniejszych ${ }^{27}$. W roku 1959 na łamach „Pamiętnika Słowiańskiego” opublikował Kowalenko sprawozdanie

25 S. Urbańczyk, Z miłości do wiedzy. Wspomnienia, Kraków 1999, s. 390-392.

26 "Nauka Polska” 1956, r. 4, nr 4, s. 206-212.

27 Zob. m.in.: „Przegląd Zachodni” 1956, r. 12, nr 1-2, s. 188-201; tamże 1956, r. 12, nr 9-10, s. 399-403; tamże 1958, r. 14, nr 3, s. 223-228. 
z Konferencji Komitetu Słowianoznawstwa PAN i Komitetu Redakcyjnego SSS z udziałem slawistów państw słowiańskich w Poznaniu obradującej w dniach 15-17 maja 1959 r. Pragnę dodać, że konferencja ta miała przełomowe znaczenie dla dalszych losów SSS. Dzięki niej nawiązano tak potrzebne redakcji bliższe kontakty ze slawistami z Czechosłowacji i Jugosławii, z którymi konsultowano hasła SSS dotyczące południowej Słowiańszczyzny, oraz możliwość dostępu do najnowszej zagranicznej literatury. Zmieniono też koncepcję SSS z wydawnictwa dwutomowego na wielotomowe. Artykuły o powstającym SSS Kowalenko publikował także w 1959 r. w Studiach i materiatach do dziejów Wielkopolski i Pomorza, jak choćby ten zatytułowany SSS na nowym etapie pracy, a w "Slavia Occidentalis” przedstawił dłuższą relację SSS w świetle głosów krytyki o Zeszycie dyskusyjnym ${ }^{28}$. Wykorzystując różne możliwości dla poinformowania szerokiej opinii publicznej o pracach nad SSS, nie rezygnował też z prasy społeczno-kulturalnej („Tygodnik Zachodni”) ani popularyzującej wiedzę historyczną („Z Otchłani Wieków”). Publikowane tam artykuły zawierały nie tylko informacje o stanie prac nad Słownikiem, ale przede wszystkim wyrażały jego troskę o obecne losy oraz o przyszłość wydawnictwa ${ }^{29}$. Pisał on m.in.: "Nie trzeba szerzej uzasadniać potrzeby opracowania słownika, który by spełniał rolę naukowego kompendium z całokształtu dziejów kultury Słowian starożytnych. Jest to zadanie stojące przed nauką nie tylko polską, ale i innych narodów, jak dotąd nie zrealizowane w żadnym środowisku naukowym świata”. Wydany w 1958 r. "Zeszyt dyskusyjny” miał stanowić podstawę dyskusji nad koncepcją Stownika i podjęcia decyzji, czy ma to być opracowanie popularne czy obszerne dzieło o charakterze encyklopedycznym, obejmujące dzieje Słowiańszczyzny do roku $1200 \mathrm{w}$ świetle kilku dyscyplin naukowych: antropologii, archeologii, etnografii, historii, prawa, zagadnień gospodarczych i społecznych, językoznawstwa, piśmiennictwa, sztuki i wierzeń. Zwyciężyła koncepcja druga, a zespół redakcyjny zorganizowany w Poznaniu podjął dalszą pracę z uczonymi polskimi, konsultując się w miarę możliwości także z badaczami Słowiańszczyzny z innych krajów socjalistycznych. Tak narodziło się wielkie i jedyne tego typu dzieło zbiorowe, jakim jest SSS, realizacji którego poświęcił ostatnie lata swego życia Kowalenko, a zakończył pomyślnie wydaniem w 1996 r. ostatniego drugiego zeszytu ósmego tomu jego dawny współpracownik i następca prof. Wędzki. Jednak trzy pierwsze tomy Stownika, zawierające ponad 160 haseł autorstwa Kowalenki, są niewątpliwie wynikiem jego starań, zapobiegliwości i energii włożonej w ich powstanie.

28 Studia i materiaty do dziejów Wielkopolski i Pomorza, t. V, z. 2, pod red. Z. Kaczmarczyka, Poznań 1959, s. 271-273; „Slavia Occidentalis” 1961, t. 21, s. 199-206.

29 "Tygodnik Zachodni” 1958, r. 3, nr 34, z 23 sierpnia 1958 r.; "Z Otchłani Wieków” 1957, r. 23, z. 5, s. 277-281. 
Przedstawiony powyżej przegląd publikacji prof. Kowalenki jako badacza Słowiańszczyzny nie jest, oczywiście, przeglądem całego jego dorobku naukowego w tym zakresie, na który składają się choćby hasła jego autorstwa opublikowane $\mathrm{w}$ pierwszych trzech tomach SSS oraz wiele nieopublikowanych materiałów, takich jak: liczne referaty, setki ekscerptów z obcojęzycznych wydawnictw źródłowych i opracowań zwłaszcza z literatury niemieckojęzycznej i z krajów byłej Jugosławii. Artykuł ten ma na celu przede wszystkim ukazanie stopniowego rozwoju zainteresowań badawczych profesora i wskazanie kierunku, w jakim one zmierzały do końca jego życia. Może też skłonić nas do refleksji i pytania: $\mathrm{w}$ jakim stopniu czasy i miejsca, $\mathrm{w}$ jakich przyszło żyć Kowalence, wpłynęły na jego losy zarówno osobiste, jak i naukowe? To jednak pozostawmy w sferze spekulacji myślowych, które przy tak barwnym i powikłanym życiorysie same się nasuwają. Patrząc na Kowalenkę jako badacza Słowiańszczyzny z perspektywy połowy wieku, jaka upłynęła od jego śmierci, można stwierdzić, że o ile jego postać niemal zupełnie zakryły mroki zapomnienia, o tyle jego dorobek naukowy, pomimo upływu czasu, nadal jest wykorzystywany przez licznych badaczy i cytowany w ich pracach, a SSS stanowi jedyne na świecie, pełne, encyklopedyczne kompendium wiedzy o wczesnośredniowiecznej Słowiańszczyźnie.

Wojciech Mądry

\author{
Władysław Kowalenko - \\ zapomniany poznański prekursor badań \\ nad rolą morza dla studiów słowiańskich \\ we wczesnym średniowieczu
}

\begin{abstract}
Streszczenie
Artykuł przedstawia sylwetkę i losy zmarłego przed pięćdziesięciu laty, a dzisiaj niemal zupełnie zapomnianego związanego z Poznaniem badacza Słowiańszczyzny, Władysława Kowalenki. Wykazana jest $\mathrm{w}$ nim zarówno nieliczna literatura odnosząca się do jego osoby oraz przede wszystkim niewykorzystane dotychczas liczne materiały archiwalne. W dalszej części przedstawione są wczesne zainteresowania Kowalenki skupiające się wokół osadnictwa grodowego Wielkopolski, oraz jego działalność w okresie okupacji na tajnym Uniwersytecie Ziem Zachodnich. Czasy, w jakich przyszło mu żyć po wojnie, a także sytuacja polityczna epoki PRL wywarły niebagatelny wpływ na kierunek jego dalszej pracy naukowej. Pomimo tego, oraz podeszłego już wieku w ostatnich kilkunastu latach jego życia nastąpił znaczny rozwój jego zainteresowań badawczych związanych z dziejami morskimi Słowiańszczyzny zachodniej i południowej, znajdujący swój wyraz w licznych publikacjach. Kierował też pracami redakcyjnymi jedynego wielotomowego kompendium wiedzy o wczesnej Słowiańszczyźnie jakim jest do dzisiaj Słownik starożytności słowiańskich. Obecnie dorobek naukowy Kowalenki nadal jest wykorzystywany przez badaczy i cytowany w ich pracach
\end{abstract}




\title{
Władysław Kowalenko - a forgotten pioneer of research on the importance of sea for the Slavic nations in the early Middle Ages from Poznan
}

\begin{abstract}
The articles presents the character and the life of Władysław Kowalenko, a researcher in Slavic studies connected to Poznan, who died 50 years ago and is now almost entirely forgotten. The article presents primarily the archive materials which had not been used so far, and includes the scarce pieces of literature concerning Kowalenko. The subsequent part of the article presents his early interest in the town settlements in Greater Poland and his activity during the occupation in an underground University of the Western Lands. The times in which he lived after the Second Wold War and the political situation of socialist Poland significantly influenced the direction of his academic work later on. It can be noticed that in the final years of his life, despite the circumstances and despite his advanced age, a significant development of his research interests related to the marine history of the western and southern parts of the Slavic area can be observed, which was expressed in numerous publications. Kowalenko also supervised the editorial work on the only multi-volume encyclopedia concerning the early Slavic history - the "Dictionary of Ancient Slavic History". At present, the academic legacy of Kowalenko is still used by researchers and quoted in their works.
\end{abstract}

